\title{
The Study of Valmiermuiža: History and Owners, Manor house and Closed Garden
}

\author{
Jānis Zilgalvis, a full member of the Latvian Academy of Sciences, Latvia
}

\begin{abstract}
Valmiermuiža is situated in the north of Vidzeme and borders with the town of Valmiera. The manor is less known than its other outstanding "sisters", for example, manors of Mazsalaca (Valtenbergi), Cesvaine, Dikḷi and others. The most famous person among the owners of Valmiermuiža is Elisabeth von Hallart, who was an initiator of the movement of Brothers' congregations in Vidzeme, which turned into the wakening movement of common people. There were other owners but they were less known than the von Loewensterns who left valuables items. There is little information available on the manor's park, and no research has been conducted regarding the closed garden. There is an urgent need to include the manor buildings in the list of the state protected cultural monuments in order to protect them from wrong building activities and other modifications that are not in accordance with the historical cultural environment and spatial structure of the plan.
\end{abstract}

Keywords: protection and preservation of architectural and cultural heritage, parks and gardens, investigation of the manor house architecture

\section{Introduction}

Previously the research on the manor of Valmiermuiža (in German: Wolmarshof) was conducted in 1986, and that material was a valuable source of information for further research but new information appeared in literature and archives [1]. However, it is not available to a wider audience because no one published it. One of the most known sources of information of the town of Valmiera and its neighbourhoods is the book written by researcher H. Enzelinš who wrote a book, and in 2019 it had the second edition, this time supplemented with commentaries [2]. An unusual centre of the manor, its owners in the course of time, the remains of the castle tower and the closed garden seemed interesting enough to conduct a more detailed study of the area of Valmiermuiža with more detailed research of the archive materials. The ensemble of the manor buildings of Valmiermuiža is extremely large therefore the article focuses only on the history, the family of owners, the manor house and the closed garden. The buildings for business activities, the park and the whole layout of buildings are worth of a separate study, therefore the description of them are not included here.

In fact, the life of Elisabeth von Hallart, the manor's owner and the wife of the general L.N. von Hallart, has been described before in relation to foundations of Latvian Brethren Congregations and the expansion of this movement in Vidzeme. However, her biography has not yet been studied in detail, which was the reason to examine her life in the context of Valmiermuiža's development. The article also presents an accurate comparison of the paintings of the manor house tower with the samples in the Alhambra Palace ensemble in Spain.

\section{History and Owners}

In 1622 the Swedish troops occupied Valmiera county. The Swedish king Gustavus Adolphus presented the district of Valmiera castle, which included the manors of Wolmarshof, Zempen, Muremoise and Kokenhof to Axel Gustafsson Oxenstierna (1583-1654), the State Chancellor and a diplomat. During the life of his heirs the process of manor reduction occurred and thus Valmiermuiža manor became the property of the state. Then it was leased to Johann von Reiter, a merchant from Riga. He leased the manor to Peter Bachmann who became a permanent leaser. During the Great Northern War, Valmiermuiža was heavily damaged, buildings were burned, crops and cattle were robbed. Only the sauna building remained unburned, but the mill had already collapsed. Then in 1713 the manor was leased to the lieutenant David Bachmann, a son of the P. Bachmann.

In the next years the history of the Valmiermuižas was closely linked with Magdalene Elizabeth von Hallart. She was born in 1683 in the family of Johan Gustaf von Bülow in Kortenhof manor. During the Great Northern War in 1705 she got married with Hans Georg Leyon (? - 1708), who was a major of the Swedish army, and he was also an owner of the manors of Qurellen and Kudum. He soon died in the battle at Lesnaya in 1708. Both their sons died during the plague epidemic. In 1710 the widow married for the second time with Ludwig Nikolaus von Hallart (1659-1727), who was the general of the Russian army and they continued to live in Kortenhof manor. The newly married husband was occupied with his service in the army: he served in the army of Saxony for a long time, 


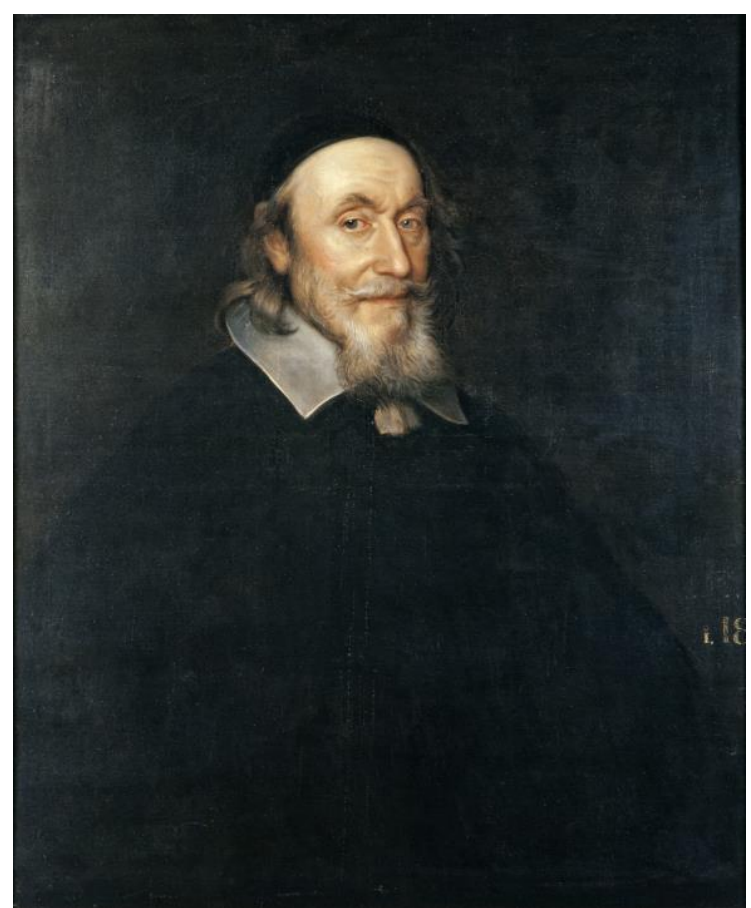

Fig. 1. Axel Oxsenstierna. The artist David Beck [internet resources]

in 1700 he was recommended by the Polish king Augustus II to become a commander of the Russian army, where he spent many years. After the failure of the siege of Narva, he was captured by the enemy and was held in captivity for one year in Sweden up to 1705 . After the release, he returned to the Russian army and participated in several battles, including the battle at Poltawa. He was awarded the Order of St. Andrew, the highest award of the Russian Empire for successfully defeating one part of the Swedish army. However, the siege of the fortress of Stralsund in 1712 along with the Russian, Polish and Danish armies was not successful, and the general retired. In 1716 Ludwig Nikolauss von Hallart together with his wife moved to Saxony. In Dresden the wife of the general got acquainted with the count Nicolaus Ludwig von Zinzendorf (1700-1760) who in 1722 on his land property established the first Herrnhut Brothers congregation in Germany. Magdalene Elizabeth von Hallart was fascinated by the new movement and became a keen supporter of it. In 1721 M. E. von Hallart stayed in the court of St. Petersburg for some time and then returned to Vidzeme. The manors of Valmiermuiža, Muremoise, Burtneck and Schwarden were leased rent-free to General Hallart for his lifetime. After the death of the general in 1727 the widow inherited the manors [3]. Due to her husband's great merits and devoted service to Russia, the lease was extended. The first mission of Herrnhut Brothers congregation arrived in Riga at her invitation in 1927. Its brothers went to Valmiermuiža to establish a community following the example of Herrnhut congregation.

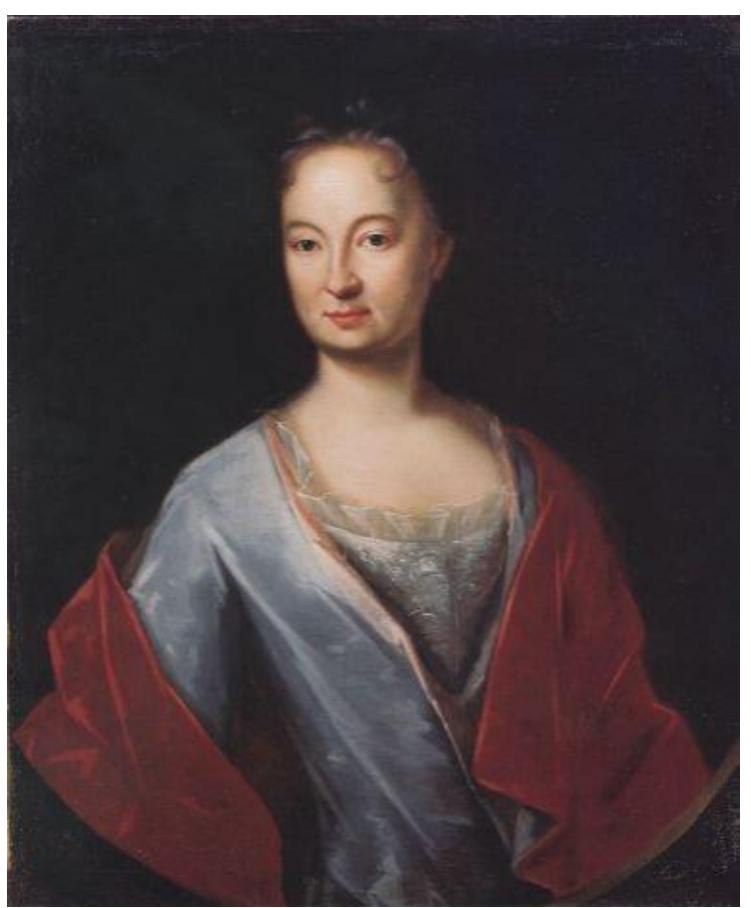

Fig. 2. Magdalene Elisabeth von Hallart

[the original is kept at the Headquarters of the Moravian Church in Herrnhut, Germany]

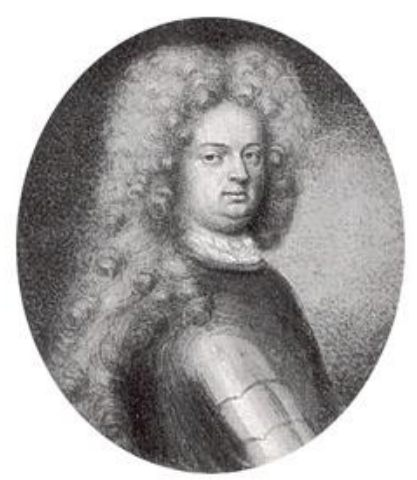

Fig. 3. Ludwig Nicolaus von Hallart [internet resources]

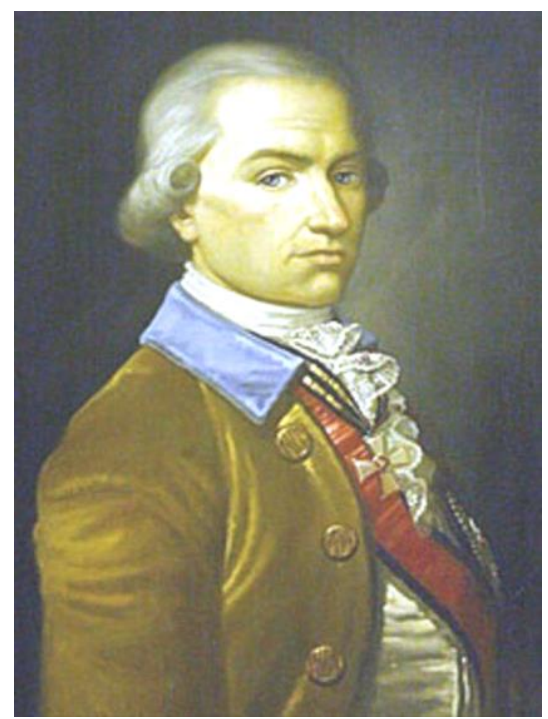

Fig. 4. Peter August Friedrich Prinz von Holstein - Beck [internet resources] 


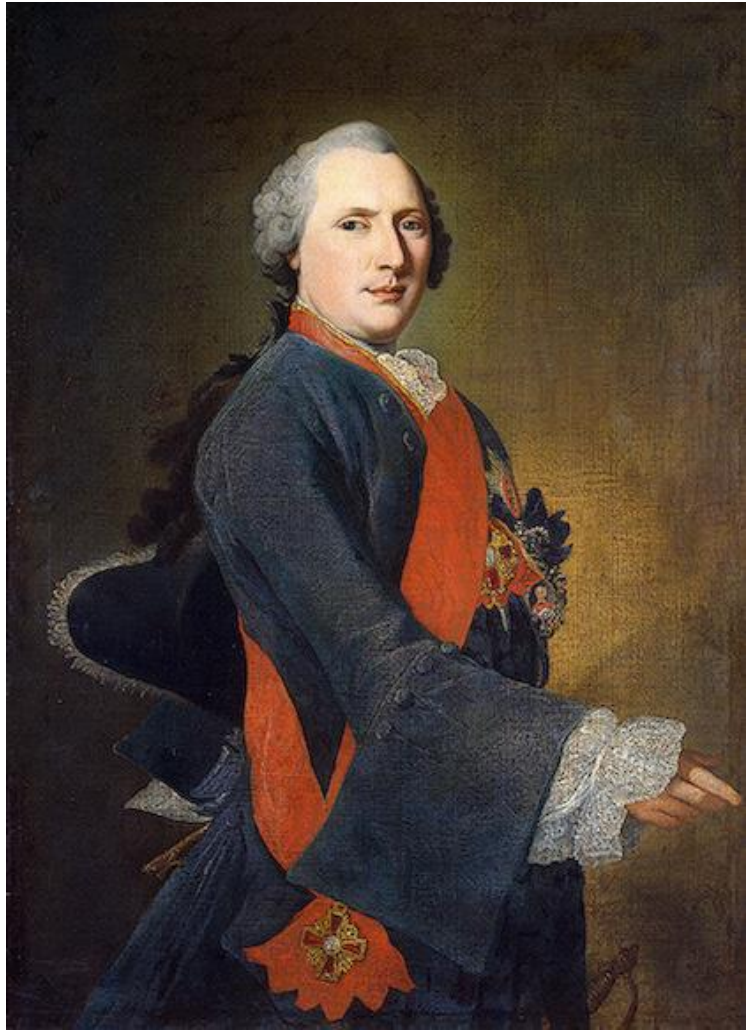

Fig. 5. Carl von Sievers [internet resources]

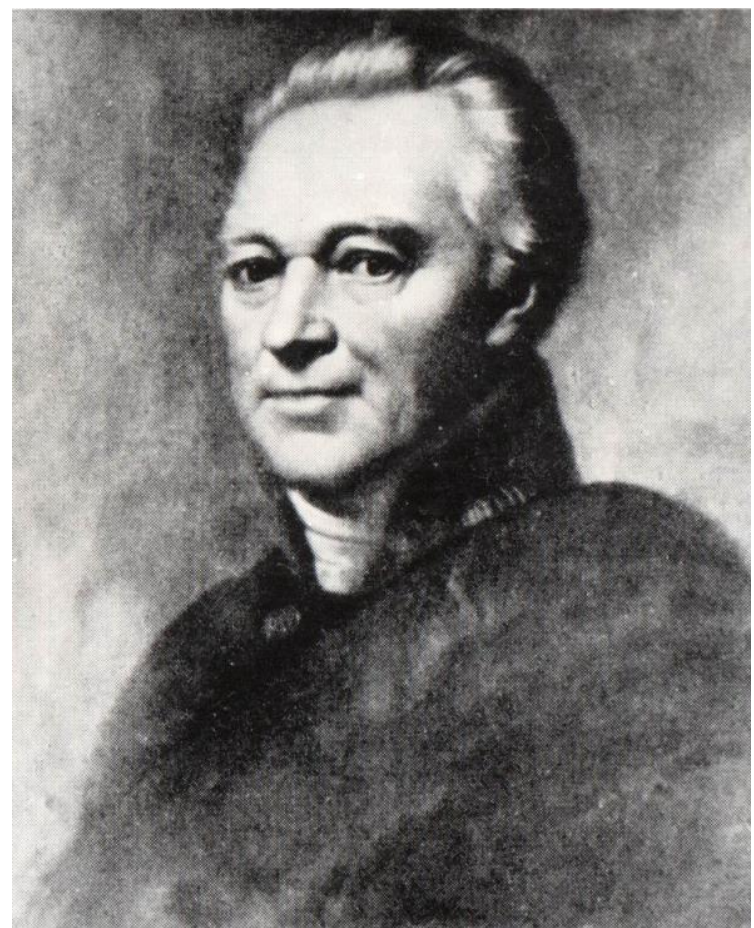

Fig. 6. Karl Otto von Loewenstern. Reproduction of the painting of an unknown author

[National Culture Heritage Department]

In 1738 a new building for a previously established peasant school was built. M. E. von Hallart built a school for training Brothers congregation's teachers or the deaconate for assistant pastors of the Valmiera county parish [4] on the right bank of the river Gauja at the end of the Diakonāts street as it is called today. A smaller community house was built next to the deaconate for Latvian congregation meetings, but later a bigger house was erected with one hall for Latvian and another hall for German congregation meetings [5].

Unfortunately, no written records about the appearance of the master's house of Valmiermuiža have been found from the time when M. E. von Hallart lived, but the building had to be worthy enough for von Zinzendorf himself to visit it in 1736 and work with the manor's owner on the plan of the development of the Herrnhut movement in Vidzeme [6].

When M. E. von Hallart died in 1750 [7], the state leased Valmiermuiža for 12 years to baron Carl von Sievers (1710-1774), which later received the title of the count and a chief marshal of the court. The archives keep the information that Carl von Sievers, the owner of the manor, disregarded the interests of the townspeople of Valmiera and ordered to build a mill on the river Rute in around 1753 . Also, in addition to Valmiermuiža manor, he managed to lay hands on the hill of Jēri and made it his property [8]. The hill of Jëri previously was allocated to the priest of the Valmiera parish. Further, in 1762 Catherine II, the Empress of Russia, presented Valmiermuiža manor as a gift to Peter August Friedrich Schleswig - Holstein - Sonderburg - Beck (1696-1775). He was a field marshal in the Russian Imperial Army, Governor of Estonia, Prince of Holstein - Beck, a participant of the Russian Turkish war and the war between Russia and Sweden, he received the Order of Saint Alexander Nevsky, the Order of Saint Ann and other awards. In 1723 Peter August married Princess Sophie of Hesse-Philippsthal, but she died in 1728 at the age of 33. Then in 1742 he married for the second time with Countess Natália Golovine (1724-1767). He paid more attention to his property, which he owned for only five years. He was the one who initiated the creation of the famous Irši garden, a special area for the breeding of deer. During the time of Prince Peter August Friedrich, between the years of 1762 and 1762 a new manor house was built which had the features of a palace. Its long facade was thought to have been originally covered with a loft under the roof. A sketch of a Valmiermuiža manor house was found with a tall three-storeyed building with a loft under the roof, but it has not been implemented [9]. A good condition of the manor in the 18th century was evidenced by the fact that Empress Catherine II stayed in the manor house in 1764. Unfortunately, the prince did not own the manor for a long time, because in 1766 he asked the queen to allow the property to be sold and received an approval. The same year the manor was sold to Countess Bazewitz, a widow of Count Wachtmeister, who was a secret advisor, for 130,000 
state thalers [10]. In 1773 she sold the property to Karl Dietrich von Loewenstern (1726-1783), who was a county sheriff.

He added a new two-storey building to the existing manor house. Later the manor was inherited by his son Karl Otto von Loewenstern (1755-1833). He had studied in Berlin and Gettingen and travelled around Germany, France, Italy and England. In 1766 he returned to Vidzeme, married Anna Mary Gotlieb von Bayer (1761-1832). After his death Valmiermuiža was inherited by his sons Karl Dietrich Georg, Andreass Magnuss Otto and Dietrich Johann Heinrich. The manor was the property of the family of von Loewensterns for almost 150 years. One of the last family members Karl Dietrich Georg von Loewenstern died in 1835 without leaving any offsprings. In order to earn more money, he established new livestock farms on the peasants' land and expanded the vodka distillery. The amount of obligatory labour (corvee) for peasants also increased. The property of Valmiermuiža was inherited by his brother Andreas Magnuss Otto who also owned the manors of Stockmannshof and Kokenhusen. Afterwards Valmiermuža was inherited by his son Otto Eduard in 1855. His wife was Countess Elisabeth von Keyserling. He died a young man in 1863 leaving three minor sons. One of them Carl Otto Edgar inherited the manor. He died on the island of Corsica in 1889 (he was born in 1853). In 1919 Valmiermuiža was taken over by the state. The area of land during that period were distributed as follows: 567 purvietas ( 1 purvieta $=0.37 \mathrm{ha})$ of arable land, 304 purvietas of grassland, four purvietas was occupied by an orchard, 120 purvietas of a park. Besides, semi-manors of Āžakalns, Pilāts, Luce, Buka, Vagulis, Sipe, Pidriķis and Jaunā also belonged to Valmiermuiža manor. As regards the location of Valmiermuiža manor, it was in its present place already at the end of the 17 th century, as evidenced by the map of Valmiera town, Valmiermuiža and peasants' land designed by O. Lundgren [11]. The economic development of the manor during the Swedish rule was evidenced by its own glass manufacturing factory, the so-called glass shed located northeast of Škēpi meadow [12]. The property of the manor suffered greatly during the Northern War. Buildings were burned, cereals and cattle destroyed. The war was followed by plague epidemics that did not spare also Valmiermuiža. For example, 593 people were still alive and 598 were dead in 1712. Later it was mentioned in the audit reports during the time of M. E. von Hallart in 1731 that all buildings were in a good condition, in the cattle farm of Kaposti a double threshing barn and a cattle yard were build, the clearance land was sparse and it had poor and moist soil. Each year six purvietas were cultivated. The mill used to be on the river, but for many years it was empty and abandoned. There were three pubs. One was located at Valmiera town, another one was called Sipe pub, and the third one was called Pleppe Krug. Each of them were newly built. It was mentioned that the timber as well as firewood were brought from far away which had to be transported one and half miles [13]. The report of the audit in 1744 provided the similar information.

\section{The manor house of Valmiermuiža, later a palace in the second part of 17th century to 1940}

The palace of Valmiermuiža vanished except for the tower, which is seen in a few historical photos. However, a historical evidence of the first manor house dates back to the second half of the 17 th century. It is mentioned in the inventory records of the manor of 1688 that the residential building was built of wood on masonry foundations. It had an entrance hall, two rooms and four chambers. There was a chimney in the hallway. Underneath one room and the chamber there was a cellar made of boulders. The building was covered with a shingle roof and its technical condition was poor. These documents also detailed each room and a chamber. For example, the room which was on the right side when entering the house from the yard had a door with a pair of hinges, an outside handle and a handle, which led to a chamber, then there was an old green stove on a masonry foundation with three eaves above. There were 6 glass windows in this room with square frames, all windows had hinges, hooks and latches and other devices for opening doors. Below the chimney there was an open hearth made of boulders [14]. It may be concluded from the description that a building was partly similar to peasants' house of that time, with a mantelpiece chimney in the centre and rooms grouped around it. This building burnt down in 1708 during the Northern War. By 1731 a new manor house was built. However, it also became worn out or did not satisfy the owners. As it was mentioned before, Prince Peter August Friedrich Holstein - Beck built the new manor house (palace) in the 1760 s. It was a one-storey stone building with dimensions 55.6 × 19.2 × 6 metres. Part of this building was occupied by a large hall decorated with expensive paintings [15]. It was depicted in the postcard dated back to the 20th century [16]. This visual material gives evidence that the building had one floor, it was covered with a tiled gabled roof with lower part hipped. The centre of the symmetrical longitudinal facade was accentuated by the risalite with a segmenttype gable, but the ends had triangular gables. The corners of the risalites were adorned with pilasters, but the windows had a semicircular lintels in the central part. As there were small windows in the basement, the building might have a cellar. The rooms for travellers were available in 


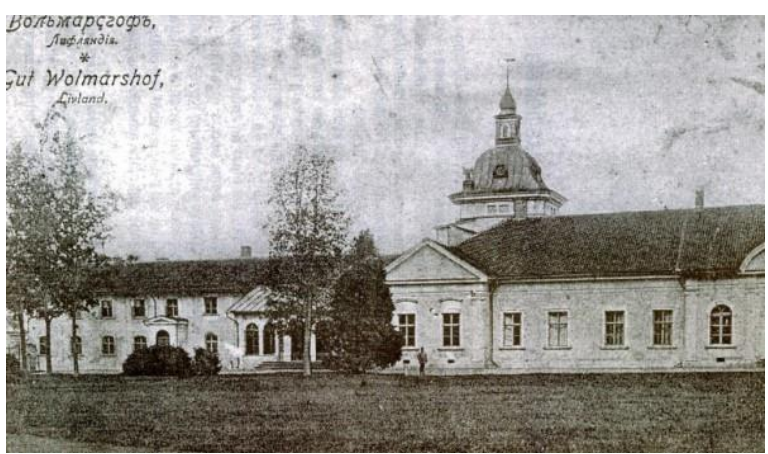

Fig. 7. Valmiermuiža [photo by the H. Treijs, the beginning of the 20th century]

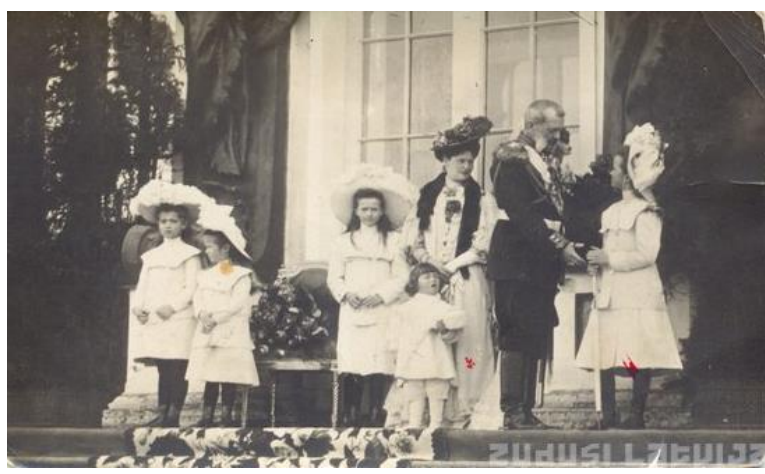

Fig. 8. Great Duke Vladimir Romanov with the family at Valmiermuiža castle [photo zudusilatvija]

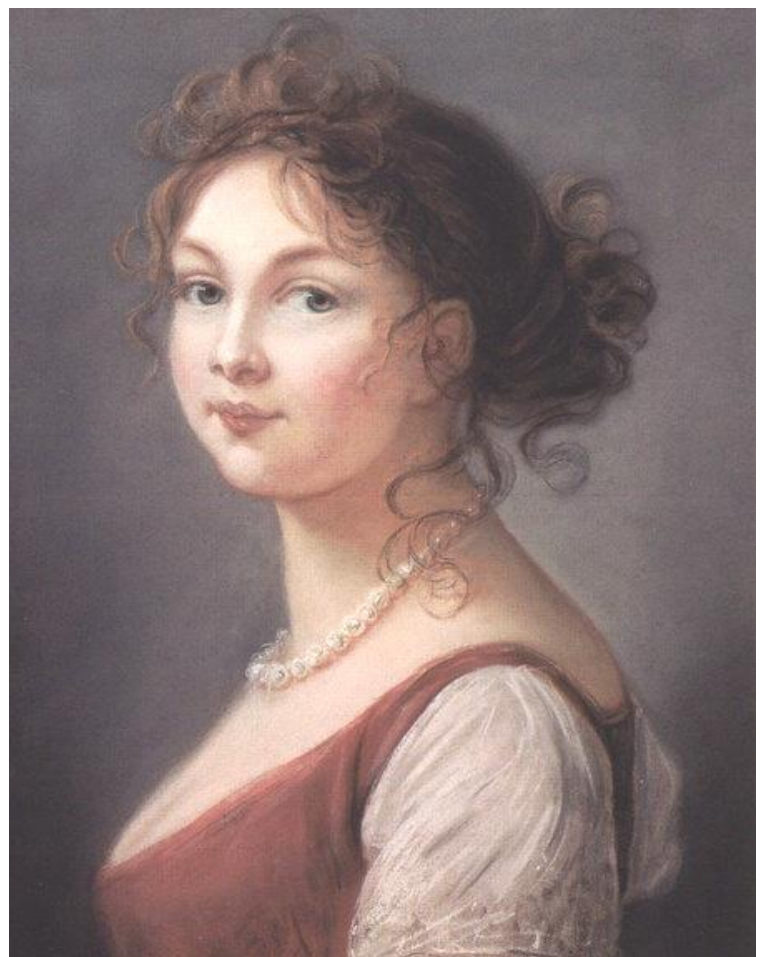

Fig. 9. Luise Auguste Wilhelmine Amalie Herzogin zu Mecklenburg [internet resources]

the palace since the main highway from the Western Europe to St. Petersburg went through Vidzeme. Certainly, these were apartments for nobility, including Empress Catherine II who could use them any time.

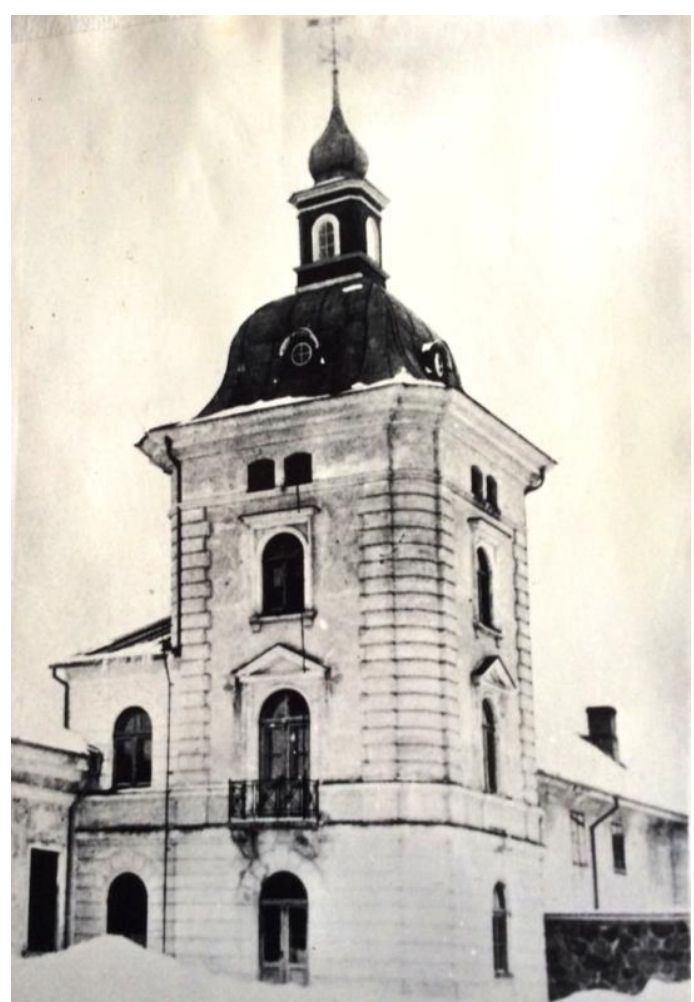

Fig. 10. The tower of Valmiermuiža palace [The photo from the beginning of the 20th century. National Culture Heritage Department]

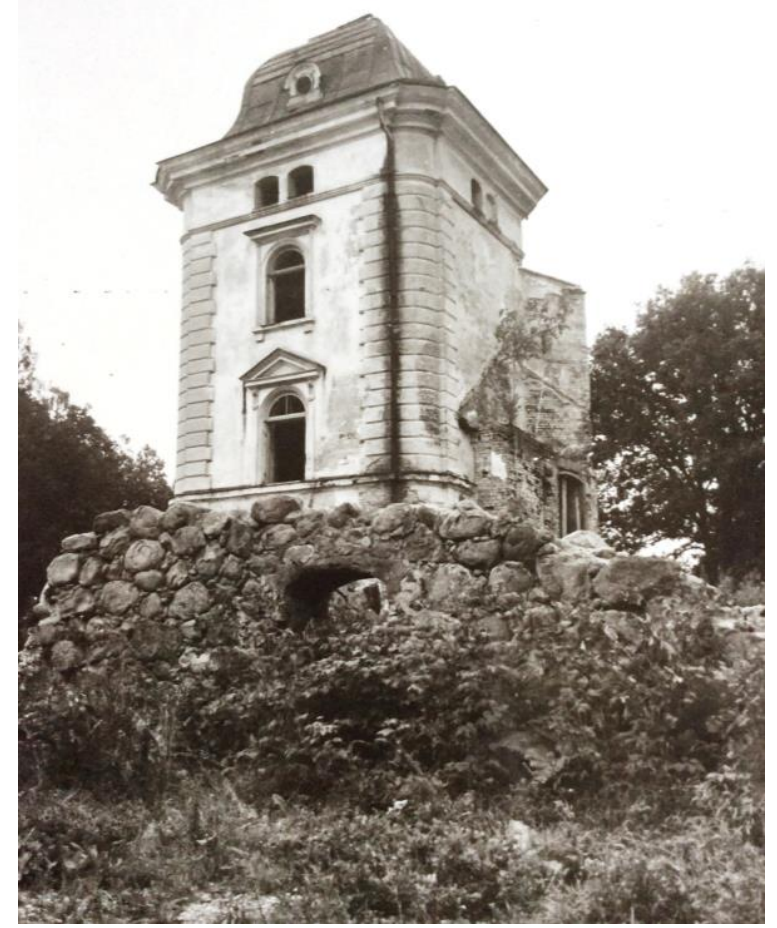

Fig. 11. The tower of Valmiermuiža palace [photo by S. Kviesite, 1974. National Culture Heritage Department]

One of the noble guests in Valmiermuiža palace was Luise Auguste Wilhelmine Amalie Herzogin zu Mecklenburg (1776-1810), who was also called Queen Louise by people. She, the wife of Friedrich Wilhelm III, wrote in her travel notes on January 1, 1809, on her way from Königsberg to St. Petersburg 
that she had arrived at Valmiermuiža, owned by Count von Loewenstern, at around 6 p.m. and was greeted by his son. "After the heavenly dinner, Prince Dolgoruki and General Duka left us and the men of their military unit handed us over to the other guards. For the first time in my life I had to spend a night under the open sky" [17]. It was meant as a joke, but it could be misunderstood by researchers in later years. In fact, the lady stayed in luxurious rooms, where the ceiling of the bedroom was painted in the blue colour to imitate the sky, but the sun was made of pieces of the mirror which looked like a mosaic. Louise's grandson, Prince Friedrich Karl, also visited Valmiermuiža at the invitation of the owner of the manor at the end of 1875 to take part in hunting in Irši garden.

In the last quarter of the 18th century following Karl Dietrich von Loewenstern's initiative, an extension to the existing palace was built at one end opposite the granary. It was a two-storey building with a gable roof. In 1918 the palace, which could now be called an ensemble, was burnt down. In 1920 its oldest single-storey section was demolished. Subsequently, in 1922, the interior of the newest part of the building began to be renovated and adapted to the needs of the six-grade elementary school of Valmiera parish. In 1926 the school was given the name of Viesturs, the Latvian legendary tribal chief. As the number of students grew, it became necessary to build a new school closer to the city, the foundation stone of which was laid in the end of 1936. The school was opened on September 1, 1938. As regards the palace, workshops of Valmiera prison were situated there. After World War II, the building housed a camp for prisoners of war, but in the late 1940s the two-storey house burned down and was not renovated anymore. During the Soviet time there was a local farm's warehouse in that part of the building of the palace which had not been damaged. The documents of the Agrarian reform of 1924 contained the following information about the palace: the palace (burnt down, length $55.6 \mathrm{~m}$, width 19.20 metres, height $6 \mathrm{~m}$, walls partially ruined), the palace (an undamaged part, two-storey 40.50, 10.50, 6 metres, respectively, the roof made of tiles is now being partially improved) [18]. Nowadays, only a tower, a small part of the basement and the foundations have remained from the palace.

\section{The tower of the palace}

The neo-baroque tower of the palace was built in 1887 because this year is written on the weather vane. The tower became the vertical dominant of the house. It is covered with a roof characteristic of a baroque style, and on its spire there is a wooden turret with the dome on top of it. A strongly protruded and richly profiled eave of the roof, the rounded corners of the tower were decorated

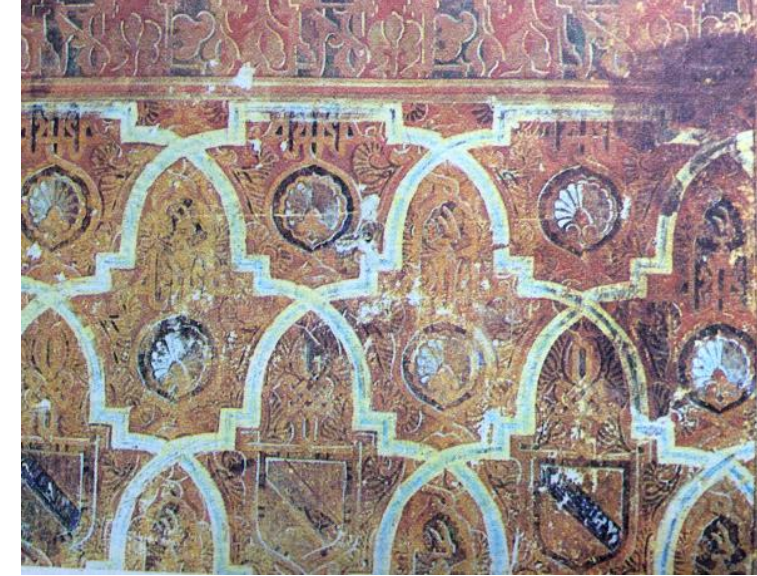

Fig. 12. The wall paintings of Valmiermuiža tower [Rundale palace museum]

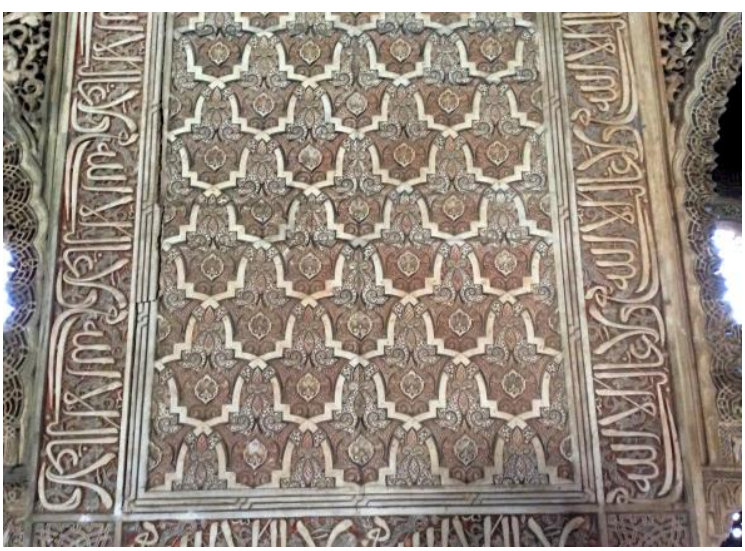

Fig. 13. Decoration of walls can be found in the Komar Castle Tower in the Throne Hall of the Alhambra Ensemble [photo by the author, 2019]
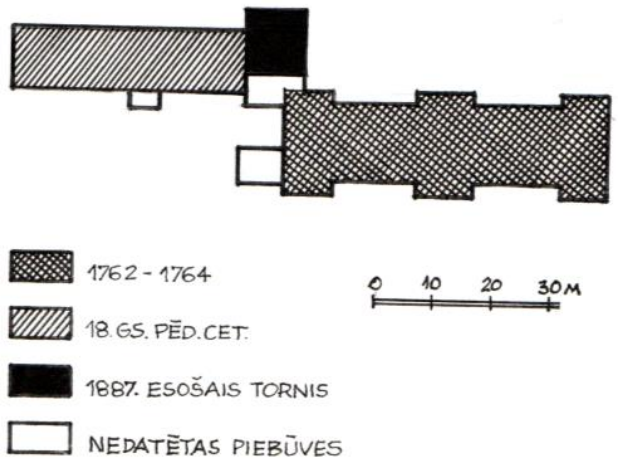

Fig. 14. The plan of Valmiermuiža manors shape before 1918. [created by the author]

with rough stones, windows of each floor had a different dressing. There is a balcony at the aperture of the second floor. The façade of the tower facing the granary outlines a contour of the lost twostorey building. However, the interior of the tower is particularly significant in the history of Latvian art due to wall paintings on three floors. They are done in the so-called Moorish style. The fashion of using the Moorish style appeared during the Rococo period and flourished in the second half of the 18th century. Alongside medieval and Far Eastern 
influence, rooms decorated with arabesque art appeared in European castles, while Moorish-style pavilions were built in parks. Such patterns of ornamentation and park buildings were probably well known in Latvia as well, mainly through engravings. The Moorish style became much more popular in the middle and the second half of the 19th century, when the interest in Islamic culture and art increased considerably. The Alhambra Palace with its fortress complex in Granada, Spain, became a source of imitation and influence. The interior design of this fantastic ensemble inspired the design of individual rooms, for example, in the Winter Palace in St. Petersburg (destroyed by the fire in 1845); Alhambra's architectural motifs were used in the park pavilion at the Linderhof Palace in Bavaria, Germany etc. As regards Valmiermuiža tower, the wall paintings have been preserved best of all on the second floor. Arabesque compositions with palm leaves, shells and Arabic calligraphy elements were situated above the panel space. The composition of paintings was surrounded by the line of Kufic script. The analogy of such decoration of walls can be found in the Komar Castle Tower in the Throne Hall of the Alhambra Ensemble [19]. The tower, according to the design of Caliph Yusuf I of the Nasrid dynasty of Granada, was the most important element which symbolized the power of the emir, where meetings of councils and official receptions took place. To emphasize the importance of the Throne Hall, the Moorish craftsmen embellished a part of the panel with ornamental tiles and the top with lacy stucco cuts, depicting plant motifs, geometric patterns and texts. The ceiling of the throne hall (1334-1354) symbolized the seven heavens of Islamic cosmogony.

Concerning Valmiermuiža, the ceiling on the second floor was decorated with geometrically arranged octagonal stars. The oriental impression was enhanced by the used colours: bright blue, red, white, brown. The stencil was used in the paintings, but some places were finished by hand. The decoration of rooms on the third floor contained a restrained Renaissance ornament. It should be noted that these unique paintings were once endangered. It happened that in 1981 the tower owners expressed their desire to demolish it. In the same year a special commission formed by the Ministry of Culture carried out an inspection of the site and concluded that it was of urgent necessity to preserve the paintings. However, nothing was done, and the building without a proper roof continued to fall into ruins. Then again in 1986 the specialists of Rundale palace museum examined the building understanding the dangerous situation of this significant object. Today the building is in no danger, but the paintings continue to turn into hard-to-see remains ...
Written sources devoted to sightseeing in Valmiermuiža did not provide exact information about the volume of the ensemble. There were also very few historical photographs and most often they documented the time when the tower was standing alone in the middle of the park. The land plans were only outlined, as it was not the task to give the exact dimensions of the buildings when it came to land borders. Therefore, a plan of the shape of the manor's palace, as it might have been before the 1918 fire, is based on the analysis of all available photos and descriptions of the building.

\section{The closed garden}

The central part of the manor building consisting of the palace, a garden, a front yard and some buildings on the left side along the edge of the garden, is worth of more detailed study. The garden is surrounded by a 1.5 meter high fence made of cut boulders. In some places it has disappeared in the course of the time. In a small section just opposite a two-storey servants' house, the fence turns perpendicular to the park. It is possible that a small pocket had been created here linked to the gates which stands free now and a fragment of masonry fence which was seen next to the two-storey master's house in 1920. The fence of the closed garden has four gates, the fifth gate is freestanding in the middle of the garden. Three of the gate posts have a similar appearance covered with a segment-type roof, but two of them are plastered with stucco finish, and the third is made of boulders, with special treatment for corner stucco finish. The other two gates are different from the previous ones but similar in construction and design. They are built of smoothly finished granite squares, with segment-type and semi-circular loose lintels, both with a highlighted lock. These last gates are made in the tradition of classicism; the gates on the side of the road opposite the two-storey servants' house are especially expressive. The next gate leads to cobblestone pavement, which is parallel to the masonry fence but situated outside it. It is possible that this road, which also passes a small house for servants, to which a fragment of the masonry fence adjoins, previously, was not meant for others to see.

The oldest, available information about the Valmiermuiža centre and its buildings is from 1688. It is the plan of Valmiera town and the surrounding land made by Eberhard Tolck, a surveyor and auditor from Riga [20]. The location of Valmiermuiža was indicated as a small simple building inside the fence at the top of a wide area. There were several sections in it that could mean less important buildings. Three roads from different sides led to the gate of the fence. The fence was probably made of wood, but it is impossible to infer from a drawing what kind of building it was. 


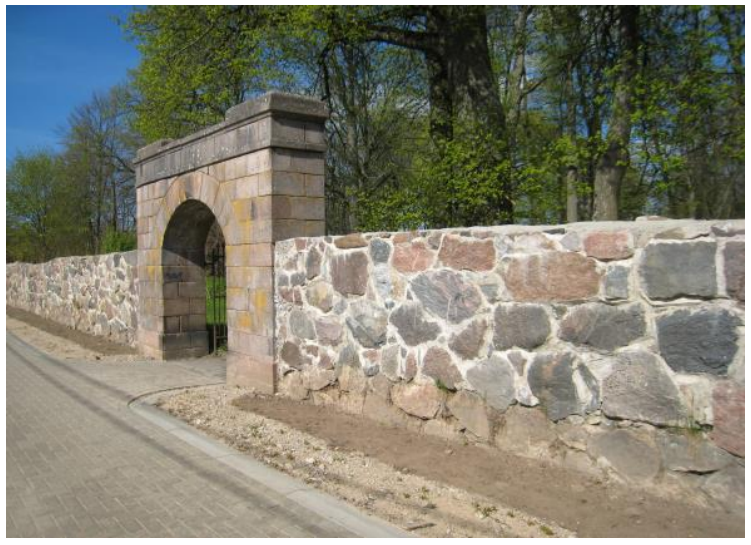

Fig. 15. The fence of the closed garden with the gate [photo by the author, 2018]

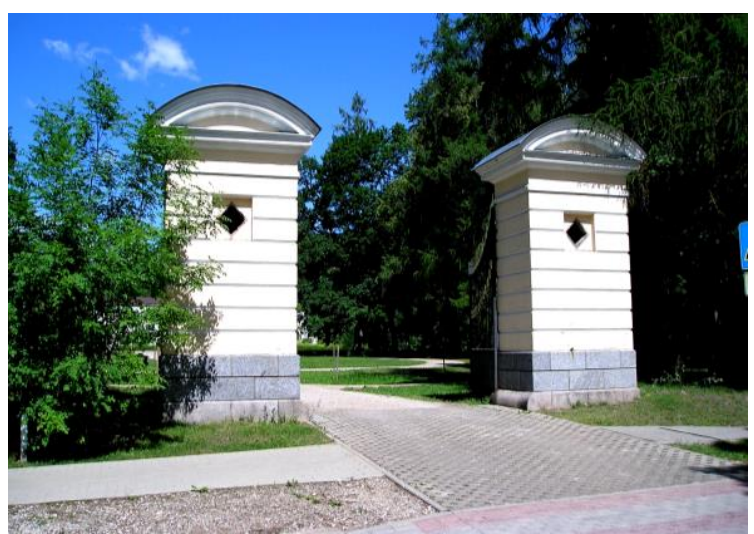

Fig. 16. The gate of the closed garden [photo by the author, 2019]

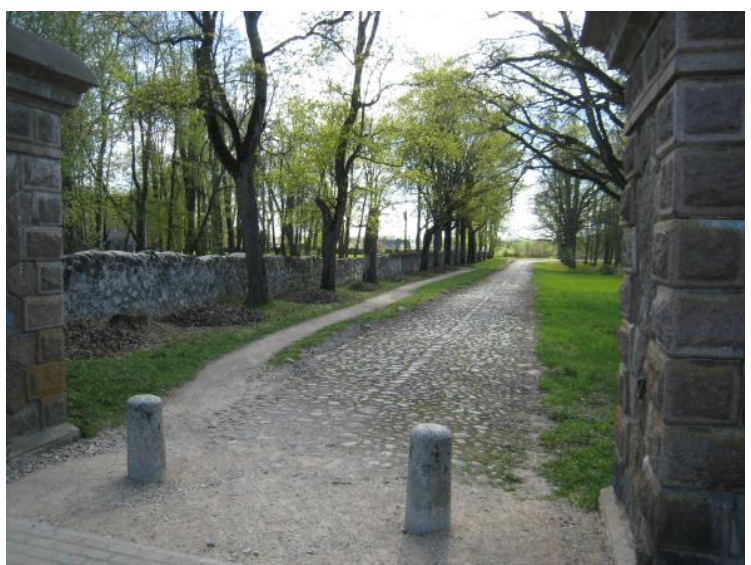

Fig. 17. The road from the gate along the fence of the closed garden [photo by the author, 2019]

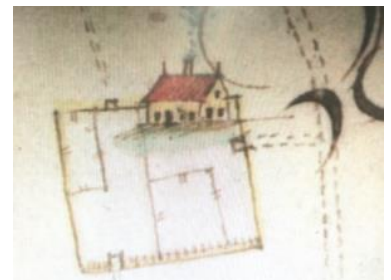

Fig. 18. The plan of Valmiera town and its vicinity. 1688., E. Tolks [Latvia State Historical Archive, 7404.f., descr. 1., p. 1381]

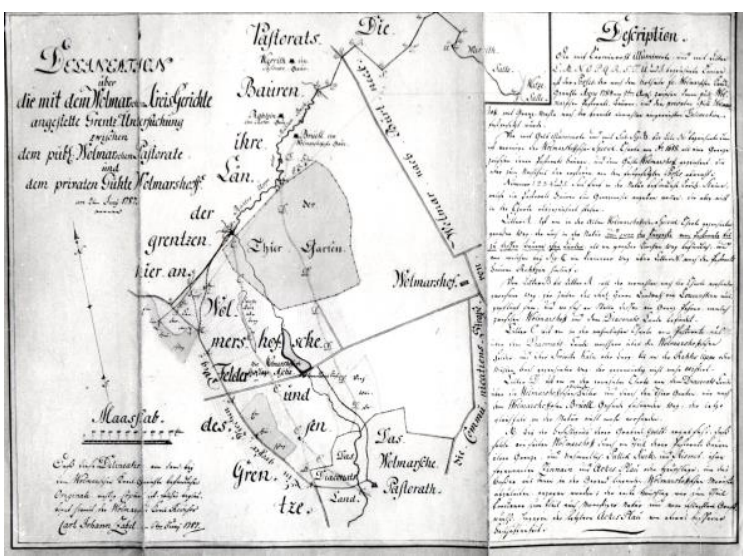

Fig. 19. Land plan of Valmiermuiža and Valmiera pastorate 1787., K. J. Cābels [Latvia State Historical Archive, 6828. f., descr. 2., p. 1259]

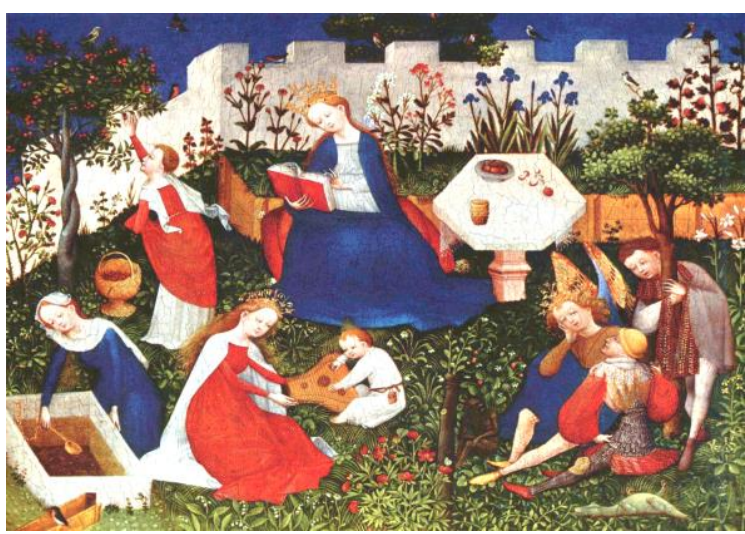

Fig. 20. A small paradise garden. A painting of an unknown German painter (around 1415), which depicts a scene of

everyday life in the closed garden [Internet resources]

The buildings were built inside a closed yard at that time. In the land plan of Valmiermuiža and Valmiera pastorate in 1787 made by Karl Johann Cabel, a crown auditor and land surveyor, only one manor house was drawn, but here a much larger area was depicted and therefore the drawings were more schematic [21].

Certainly, the situation changed over time, new buildings were built, new masonry fence was built, but the principle of including the centre of ensemble in a rectangular piece of land remained. This situation was best seen in the Land plan of Valmiermuiža issued in 1817 [22]. Thus the both sides of the castle had adjusted buildings. At one end of the palace, which was the main building, there was the front yard with a circular driveway, but at the other end there was a garden of a typical design, which was crossed by paths dividing the area in almost square shapes, according to the tradition of a closed garden. There was a small building at the end of the garden in the axis of symmetry opposite the main part of the palace, but on the left side three buildings were lined up along the edge of the garden. All this group, as already mentioned, was relatively enclosed in a rectangular area 


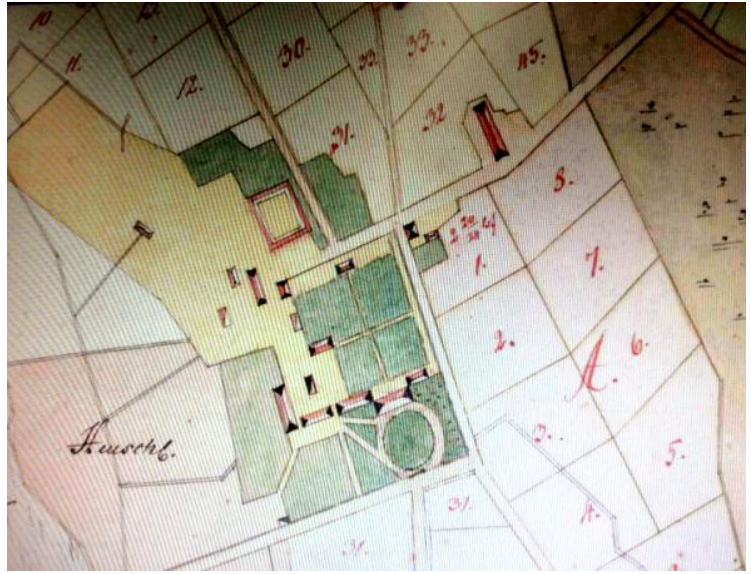

Fig. 21. The land plan of Valmiermuiža with the location of buildings in 1817

[Latvia State Historical Archive, 6828. f., descr. 2., p. 1272]

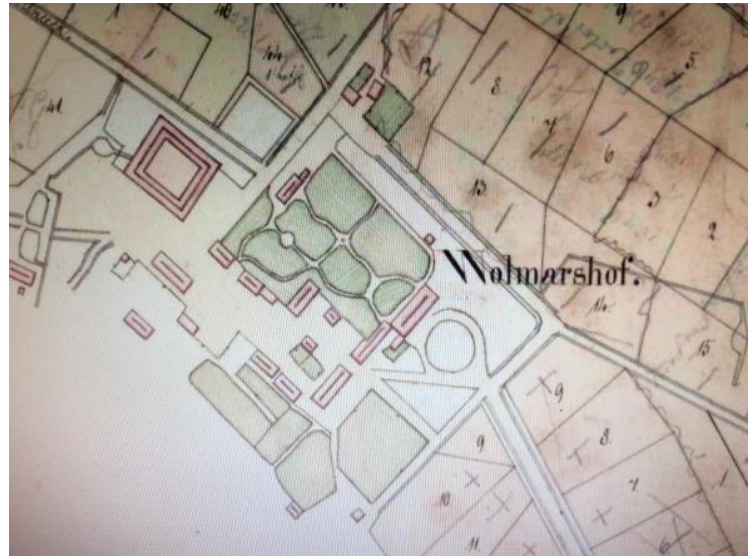

Fig. 22. The land plan of Valmiermuiža land. 1843., auditor F. Wischnakowsky

[Latvia State Historical Archive, 7404.f., descr. 1.p. 1381]

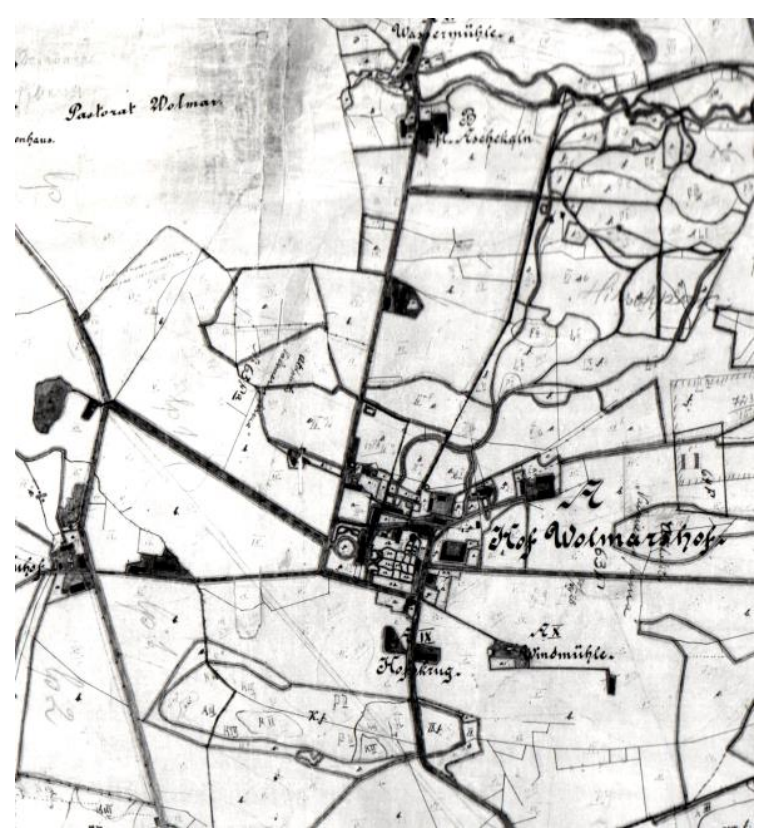

Fig. 23. The land plan of Valmiermuiža. 1843 [Latvia State Historical Archive, 1679. f., descr. 156. p. 144] surrounded by a masonry fence with a gate, which, as already mentioned, has mostly survived to this day. Thus, this central part of buildings formed the so-called closed garden.

As it can be seen in the map of 1843 "Feld Charte Wolmarshof", worked out by F. Wischnakowsky, an auditor, a rectangular enclosed garden design was mostly preserved, only the small adjusted building on the right side of the castle had disappeared. The regular garden paths have got a zigzag configuration, although the cross shaped division was still well seen. Two new buildings have been added, one very small outside the fence on the right side, the other one on the edge of the garden facing another one on the other side of the road along the masonry fence. In the same year, 1843, the land plan of another manor was designed [23]. A small rectangular shape was built at one end of the castle, which has retained its two mentioned shapes. There was a circular road in the front yard, to the left of which there were lanes for walks around small, oval squares. The garden design on the other side of the palace had a regularity, although the corners of the lanes were rounded. On the left side of the garden there was a circular structure (a pavilion?), in front of it there was a small garden with regular features.

Further changes of the closed garden, which was a core of the layout of Valmiermuiža buildings can be traced back to the land plan of the 1920s. Such a plan was designed by the surveyor V. Blumbergs in 1925 [24]. If the garden and the front yard can still be recognized, then the buildings leave a sad impression. Only the place of the old palace built by the Prince of Holstein Beck was identified in the plan, but the building which had been on the axis of the symmetry (its function has not been discovered) at the end of the garden was not included there anymore. Only the tower and the part of the palace which was separated by the road from the granary and which built in the last quarter of the $18^{\text {th }}$ century were in the map. There were also no buildings on the left side of the garden near the road inside the masonry fence. Therefore it was difficult to read spatial structure of the closed garden of the last quarter of the 18th century - the beginning of the 19th century.

The similar evidence is provided by the land plan of 1926 [25] and the land plan of 1928 [26]. The Soviet period introduced its own corrections to the historic design of the core of the manor's centre. No one was interested or knew about the meaning of a historical layout of buildings and planning. The tower survived to become an evidence of the former manor's ensemble, even though there were repeated intentions to demolish it. The design of the 


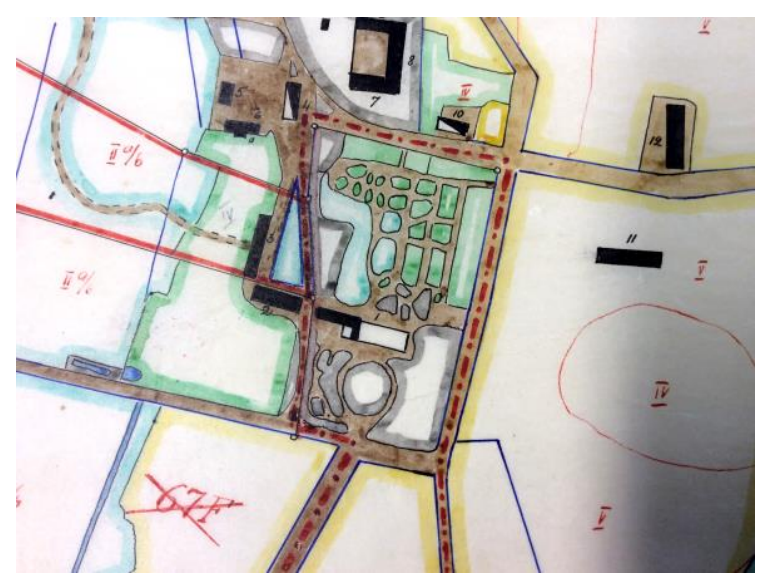

Fig. 24. The land plan of Valmiermuiža. 1925. $g$.

[Latvia State Historical Archive, 1679. f., descr. 172. p. 1950]

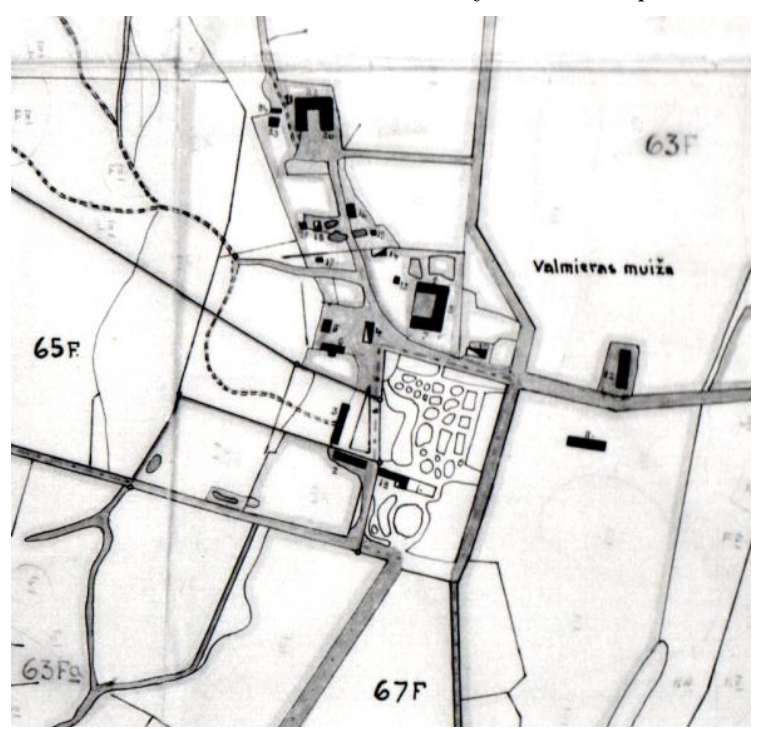

Fig. 25. The design of the changes in Valmiermuiža land plan. 1926., V. Blumbergs

[Latvia State Historical Archive, 1679. f., descr. 172. p. 1950]

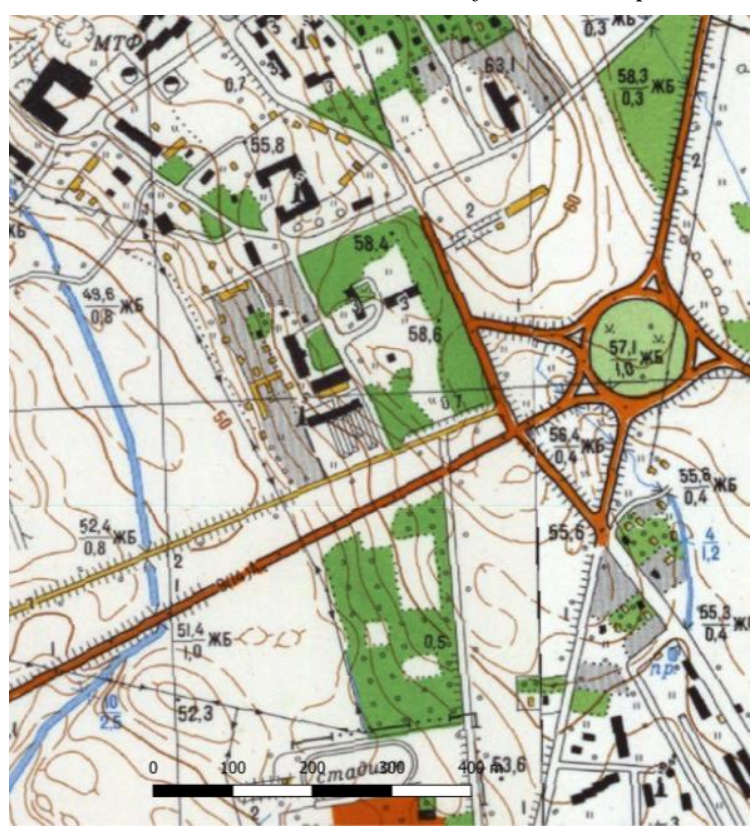

Fig. 26. Topographic map. 1967

[National Culture Heritage Department] closed garden vanished, trees and shrubs grew where they should not. In the middle of the garden two apartment buildings were built without any concerns regarding the historic value of the place. New roads led to them. But the masonry fence with the gate and an enclosed rectangular area, the ancient enclosed garden, remained. This is shown in the topographic map of 1967 [27].

No significant changes in the essence and character of the core of the manor centre have taken place in the last decades. The palace tower is lonely standing in the middle of a deserted area, people have got used to white apartment buildings, however, the well-kept and tidy masonry fence is pleasing to the eye. There is a small, expressive wooden open-air stage on the edge of the former front yard built in the wrong place.

\section{Conclusions}

There are many places in Latvia where the layout of building in the manor centre with a park can be recognized with difficulty. Valmiermuiža is not one of them, because despite the fact that the palace has vanished and new objects have been built instead of the closed garden in the Soviet period, there is a great deal of culture and historical evidence. There is enough evidence left to find out about the manor's owners over time, important and interesting personalities of their time, who not only created material values but also built self-confidence of ordinary people, such as M. E. von Hallart. The similarity of the interior paintings of the manor's tower with the Alhambra Palace complex in Granada, Andalucia, is also important, as it signifies the intentions of owners to follow the latest trends in fashion of that time. In addition, the large business and farming complex that have been preserved to large extent until today is very valuable and requires more detailed research. Also, the park of the manor, the socalled Irši garden, is worth to be investigate. However, the closed garden of the 18th-19th century should be highlighted because the changes can be traced during the centuries and its spatial environment is still present today. It is not just an enclosed area with a masonry fence with a few gates, it is the place full of feelings and emotions where you can still imagine the aristocratic life and culturally aesthetic spirit that prevailed there.

It is possible to partially restore the design of this garden, which has already been tried in the front yard, it is possible to outline the historic buildings, clean the foundations, to present information on famous people of the area using modern techniques and design, to enrich the environment with meaningful activities which are not limited to beer drinking and swings. There are many opportunities and, hopefully, this brief insight into the history of the manor, its owners, buildings and planning of its central part will raise its value in the eyes and decisions of those who are destined to care, preserve and develop it. 


\section{References}

1. İvāns, G. Valmiermuižas kompleksa vēsturiskās izpētes materiāli. Rīga, 1986., Volume 1, manuscript National Culture Heritage Department (NKMP), case Valmiermuiža

2. Endzeliňs, H. Skati Valmieras pilsētas, draudzes un novada pagātnē. Rīga: Apvārsnis, 2019.

3. General L.N. von Hallart was buried at St. Simanis church in Valmiera. A memorial plaque was erected on the exterior wall of the church in his memory. The monument was made of sandstone. The grave's plaque was covered with a portal with a segment-type gable. At the top of the plaque there is the coat of arms of the Hallart family beneath the text. The monument is now located in the altar part of the congregation room of the church as it has been damaged over time. The burial place of E. von Hallart was described by H. Endzelinšs: .....Elizabeth von Hallart at her own request, was not buried in the church where her husband was buried (but not confirmed), but in the cemetery near the church in a chapel where only one of the 4 lindens growing in the past can be found today. Endzelinš, $\mathbf{H}$. Skati Valmieras pilsētas, draudzes un novada pagātnē. Rīga: Apvārsnis, 2019., pp. 177.

4. The deaconate was marked in the 1688 land plan made by E. Tolck above the parsonate. LVVA 7404. f., 1. apr., 1381. 1.

5. Melnalksnis wrote: Jêrakalns - the place on the bank of the Gaujas from Diakonats street until deaf-mute school... Here the house of the seminar's director H. Barlach (deaconate) was located - the first meeting place of brothers' congregation in Vidzeme. In 1741 the before mentioned wife of the general together with the Unguri baron Kampenhausen built here community house and the school 23 asis $(1$ ass $=2.134 \mathrm{~m})$ long and 7 asis $(1$ ass $=2.134 \mathrm{~m})$ broad with all necessary auxiliary buildings. The former threshing barn was changed to the elementary school; this building is still there. See: Melnalksnis, A. Vadonis pa dzimtenes kalniem un lejām. I dal̦a, Vidzeme, Riga: Valstspapiru spiestuves izdevums, 1930., pp. 23. The information about building of this house in 1741 is also available in the book Endzeliṇš, H. Skati Valmieras pilsētas, draudzes un novada pagātnē. Rīga: Apvārsnis, 2019., pp.189.

6. Ceipe, G. Brāḷu draudze - pirmā latviešu nacionālā kustība. Ceḷā uz latviešu tautu. Rīga: Latvijas Nacionālais vēstures muzejs, 2018., 27. Lpp.

7. M. E. fon Hallart and her husband were buried in the churchyard in front of the locker room. The graves are decorated with three gray linden trees, one of which fell in the summer of 1926 because of old age, it was written in: Melnalksnis, A. Vadonis pa dzimtenes kalniem un lejām. I daḷa, Vidzeme, Rīga: Valstspapīru spiestuves izdevums, 1930., pp. 20.

8. Endzeliņ̌š, H. Skats Valmieras muižas pagātnē. Valmierietis, 1935., Nr. 355

9. Lancmanis, I. Vidzemes muižu arhitektūra, Rīga: Rundāles pils muzejs, 2015., 109. lpp.

10. Stryk, L. Beiträge zur Geschichte der Rittergüter Livland. Dorpat, 1871., S. 233.

11. LVVA 7404. f., 1. apr., 555. 1.

12. Endzeliňš, H. Skats Valmieras pilsētas, draudzes un novada pagātnē. Valmiera, 1932., 163. lpp.

13. İvāns, G. Valmiermuižas kompleksa vēsturiskās izpētes materiāli. Rīga, 1986., Volume 1, pp. 55. Manuscript, NKMP PDC, case Valmiermuiža

14. LVVA 7348. f., 1. apr., 10. 1.

15. Endzeliṇ̌š, H. Skats Valmieras muižas pagātnē. Valmierietis, 1935., Nr. 355.

16. https://upload.wikimedia.org/wikipedia/lv/b/be/Valmiermuiža_20._gs._sākumā_H._Treijs.jpg

17. www.rigacv./lv/articles/koroleva luiza pēc avota - Die Königin Luise in 50 Bildern für Jung und Alt. Berlin: Verlag Paul Kittel, 1896

18. LVVA 1679. f., 172. apr., 1950. 1.

19. Bayón, F., Casals, L., The Alhambra of Granada. Granada: Triangle postals, 2009.

20. LVVA 7404. f., 1. apr., 1381. 1.

21. LVVA 6828. f., 2. apr., 1259. 1.

22. LVVA 1828. f., 2. apr., 1272. 1.

23. LVVA 1679. f., 156. apr., 144. 1.

24. LVVA 1679. f., 172. apr., 1950. 1.

25. LVVA 1679. f., 172. apr., 1950. 1.

26. LVVA 1679. f., 172. apr., 1951. 1.

27. 1967. gada topogrāfiskais plāns. (NKMP)

\section{AUTHOR:}

In 1979 Jānis Zilgalvis graduated from the Faculty of Architecture of the Riga Technical University. In 1990, he defended his doctoral thesis on the subject of the manor architecture of the second half of the $19^{\text {th }}$ century and the early $20^{\text {th }}$ century. Since then, he is the Head of the Architecture Department of the State Inspection for Cultural Heritage. Since 2012 - a full member of the Latvian Academy of Sciences. Over 180 scientific and popular scientific publications and 18 books (some co-authored). The main lines of the research - the manor architecture and cultural history, sacral architecture, protection of cultural heritage.

Kopsavilkums. Savdabīgais Valmiermuižas centrs un tā īpašnieki laika gaitā, slēgtais dārzs, palikušais muižas pils tornis ar iekštelpu gleznojumiem likās nozīmīgi pieminekḷi, lai sīkāk pievērstos to izpētei, īpaši balstoties uz arhīvu materiālu padzilinātas izzināšanas. Saimnieciskais komplekss, parks un visa apbūve kopumā ir atsevišḳa pêtījuma vērta, tāpēe šeit netiek aplūkota. Vairāk iepriekšējos gados rakstīts par muižas īpašnieci generāḷa L. N. fon Hallarta sievas Elizabetes fon Hallartes darbību, kas saistās ar brāḷu draudžu 
dibināšanu un šis kustības sekmēšanu Vidzemē. Taču viṇas dzīves gājums detalizēti joprojām nav izpētīts, kas lika pievērsties arī šim jautājumam Valmiermuižas attīstîbas kontekstā. Nozīmīga likās arī pils torṇa telpu gleznojumu precīza salīdzināšana ar paraugiem Alhambras pils ansamblī Spānijā.

No 1622. gada muiža piederēja Akselam Uksenšēnam (Axel Gustafsson Oxenstierna). Tālākā Valmiermuižas vēsture ir vairāk vai mazāk saistīta ar jau minēto Magdalēnu Elizabeti fon Hallarti (M. E. von Hallart), Krievijas armijas ǵenerāąa Ludviga Nikolausa (Nikolaja) fon Hallarta (L. N. von Hallart) sievu. 1716. gadā viṇi devās uz Saksiju, iepazinās ar grāfu Nikolausu Ludvigu fon Cincendorfu $(N$. L. von Zinzendorf, kurš 1722. gadā savos zemes īpašumos Saksijā izveidoja pirmo Hernhūtes brāḷu draudzi Vācijā. Jaunā kustība aizrāva M. E. fon Hallarti un vina kḷuva par tās dedzīgu atbalstītāju. 1729. gadā pēc vinasas aicinājuma Rīgā ieradās pirmā hernhūtiešu brāḷu draudžu misija. Tās brāli devās uz Valmiermuižu, lai Jērakalnā veidotu kopienu pēc Hernhūtes draudzes parauga.

1762. gadā Krievijas valdniece Katrīna II Valmiermuižu dāvināja Krievijas armijas generālfeldmaršalam, Holšteinas - Bekas princim Pēterim Augustam Frīdriham (Peter August Friedrich Schleswig - Holstein Sonderburg - Beck). Viņš savam īpašumam, kurš gan tam piederēja tikai piecus gadus, pievērsa lielu uzmanību. Viṇa ierosmē izveidots slavenais Valmiermuižas Iršu dārzs - īpaša teritorija staltbriežu audzēšanai. Prinča Pētera Augusta Frīdriha laikā starp 1762. un 1764. gadu uzcelta jauna kungu māja, kuru var saukt jau par pili. Nākošais īpašnieks landrāts Karls Dītrihs fon Lēvenšterns $(K . D$. von Loewenstern) esošajai pilij piebūvēja jaunu divstāvu korpusu. 1919. gadā Valmiermuiža pārṇemta valsts īpašumā.

Valmiermuiža tagadējā vietā atradusies jau 17. gs. beigās, par ko liecina 1681. gada zemju plāns. No pils, kura redzama tikai dažos vēsturiskos fotoattēlos saglabājies tikai tornis. Taču vēstures liecības par senāko kungu māju sniedzas 17. gs. otrajā pusēe. 1688. gada muižas inventarizācijas aktos minēts, ka dzīvojamā ēka celta no koka uz mūrētiem pamatiem. Šì ēka nodegusi 1708. gadā Ziemeḷu kara laikā. Līdz 1731. gadam jau bijusi uzcelta jauna kungu māja. Taču arī tā laika gaitā neapmierināja muižas īpašnieku. Kā jau minēts, jaunu pili cēlis Holšteinas - Bekas princis Pēteris Augusts Frīdrihs 1760. gados. Tā bija pagara vienstāva mūra ēka. 18. gs. pēdējā ceturksnī celtā Karla Dītriha fon Lēvenšterna pils bija divstāvu èka, segta ar divslīpju jumtu. 1918. gadā pils ansamblis nodega. 1920. gadā tika nojaukta tās senākā vientāva daḷa. 1922. gadā jaunākā ēkas daḷa piemērota pamatskolas vajadzībām. 1940. gadu beigās šis divstāvu nams nodega un vairs netika atjaunots.

1887. gadā celts pils neobaroka tornis, kas kḷuva par Valmiermuižas īpašnieku mājvietas vertikālo dominanti. Tas segts ar barokālas formas jumtu, kura smailē likts koka tornītis ar sīpolveida kupolinu galā. İpaši nozīmīgs Latvijas mākslas vēsturē ir torna interjers - sienu gleznojumi telpās trīs stāvos. Tie izpildīit t. s. mauru stilā. Šim sienu dekoratīvajam noformējumam var atrast konkrētas analog̣ijas Alhambras ansambḷa Komaru pils torña Troṇa zālē.

Padzilinātas izpētes vērta ir muižas apbūves centrālā daḷa, kuru veidoja pils komplekss, dārzs, parādes pagalms un dažas ēkas kreisajā pusē gar dārza malu. Vislabāk šĩ situācija redzama 1817. gada plānā. Šodien dārzu apjož no šķeltiem laukakmen̦iem mūrēts, aptuveni 1.5 metrus augsts žogs. Tajā izbūvēti četri vārti, piektie atrodas kā brīvstāvoši dārza vidū. 1843. gada plānā taisnstūrveida t. s. slēgtā dārza tuvumā esošā apbūve kopumā ir saglabājusies, vienīgi celinini ieguvuši līkloču konfigurāciju, kaut gan krustveida dalījums vēl labi nolasāms. Šì Valmiermuižas apbūves centra kodola jeb slēgtā dārza izmaināām tālāk varam izsekot pēc 1920. gadu zemju plāniem. Mainoties apbūvei un apstādījumu raksturam 18. gs. pēdējā ceturkšņa - 19. gs sākuma slēgtā dārza apbūves telpiskā struktūra kḷuva grūtāk nolasāma.

Savas korekcijas muižas centra vēsturiskā kodola plānojumā ieviesa arī padomju laiks. Kā liecība par pils ansambli saglabājās tornis, kuru nojaukt ne vienu reizi vien bija iecerēts. Pazuda slēgtā dārza plānojuma liecības, nevietā ieauga koki un krūmi. Dārza vidū tika uzbūvētas divas daudzdz̄īokḷu ēkas. Pie tām radās jauni piebraucamie celii. Taču saglabājās mūra žogs ar vārtiem un tā iekḷautā taisnstūrveida teritorija - senais slēgtais dārzs. Nekādas būtiskas izmaiņas muižas centra kodola substancē, têlā nav mainījušās arī pēdējo gadu desmitos.

Ir daudzas vietas Latvijā, kur muižu centru apbūvi ar parku var atpazīt tikai ar grūtībām. Valmiermuiža nav starp tādām, jo neskatoties uz to, ka zudusi ir pils un slēgtajā dārzā nevietā padomju laikā radīit jauni objekti, saglabājušăs ir ḷoti daudz kultūrvēsturisku liecību. Tā ir iespēja izsekot muižas īpašniekiem laika gaitā, sava laika nozīmīgām un interesantām personībām, kuras ne tikai radījušas materiālas vērtības, bet arī cēlušas vienkāršās tautas pašapziṇu, piemēram, E. fon Hallarte. Nozīmīga ir arī muižas torṇa iekštelpu gleznojumu tiešā sasaiste ar Alhambras pils kompleksu Granādā Andalūzijā, kas liecina par aktīvu sekošanu jaunākajām stilu atdzimšanas modes prasībām. Taču sevišķi gribētos izcelt 18.-19. gadsimtā veidoto slēgto dārzu, kura izmaiņām var izsekot gadsimtu garumā un kura radītā telpiskā vide jūtama vēl šodien. Tā nav tikai mūra žoga apjozta teritorija ar dažiem vārtiem, tā ir sajūtu un emociju bagāta vieta, kurā joprojām var iztēloties to aristokrātiski sadzīvisko un kulturāli estētisko elpu, kas tajā valdīja. Ir iespējams dalēeji atjaunot šī dārza plānojumu, kas parādes pagalmā jau ir mēgināts, var iezīmēt vēsturisko êku kontūras attīrot to pamatus, var veidot ar mūsdien̄̄ga dizaina paṇēmieniem informāciju par šeit dzīvojošām un strādājošām personībām. 